\title{
The Effect of Detraining on Bone
}

\author{
Anna Nordström ${ }^{*}, 1,2$ and Peter Nordström ${ }^{1,3}$ \\ ${ }^{I}$ Department of Surgical and Perioperative Science, Sports Medicine, Umeå University, S-901 85 Umeå, Sweden \\ ${ }^{2}$ Department of Community Medicine and Rehabilitation, Rehabilitation Medicine, Umeå University, S-901 85 Umeå, \\ Sweden \\ ${ }^{3}$ Department of Community Medicine and Rehabilitation, Geriatrics, Umeå University, S-901 85 Umeå, Sweden
}

\begin{abstract}
Physical activity has been recommended for the treatment and even prevention of osteoporosis. This is because physical activity can potentially increase bone mass and strength in the early years of life and reduce the risk of falling in older populations. However, a key question that remains to be answered is whether a high bone mineral density (BMD) resulting from physical activity is sustained despite decreased activity. The aim of this review is to describe the effects of decreased levels of physical activity on bone.

A comprehensive search of Medline, EMBASE, and the Cochrane controlled trials register was conducted. Previous studies have reported that benefits from prior physical activity seem to be eroded after cessation of this activity, at least for bone sites that are rich in trabecular bone such as the clinically important proximal femur. In bone sites rich in cortical bone, there appeared to be long-term beneficial effects of physical activity.

In conclusion, bone gain through physical activity is lost in bone sites rich in trabecular bone if the activity is not maintained. However, current knowledge is limited and further prospective research into the effect of detraining is recommended.
\end{abstract}

Keywords: Osteoporosis, fractures, prevention, exercise.

\section{INTRODUCTION}

Osteoporosis is an increasingly prevalent global health care problem, which is characterized by a reduction in bone mass, microstructural deterioration with advancing age, and an increase in fracture rate. It has been estimated that $50 \%$ of all women and $20 \%$ of all men will suffer an osteoporosisrelated fracture during their lifetime. Identification and optimization of factors affecting the incidence of osteoporosis is critical for the possibility of successfully minimizing the impact of fractures, which are an important cause of mortality and painful disability in the western world [1-3].

Physical activity is considered an important modifiable environmental factor with the potential to increase (or maintain) bone mineral density (BMD) in both children and adults [4-9]. It has previously been proposed that a high peak bone mass from prior training could be protective against the development of osteoporosis later in life [10,11]. A high peak bone mass from previous physical activity may decrease the risk for future fractures, provided that the bone gained is not lost with reduced physical activity later in life.

Physical activity has therefore been recommended for the prevention and treatment of osteoporosis due to its potential

*Address correspondence to this author at the Sports Medicine Unit, Department of Surgical and Perioperative Sciences, Umeå University, 901 85 Umeå, Sweden; Tel: +46-90-7853951; Fax: +46-90-135692; E-mail: anna.nordstrom@idrott.umu.se to increase bone mass and strength in the early years of life and for its ability to reduce the risk of falling in older populations. However, it is not known whether BMD gained through exercise is preserved, decreased, or lost when exercise is stopped. This knowledge is essential if physical activity is to be regarded as an evidence-based therapy and a cost-effective treatment when it comes to increasing bone mineral density and ultimately reducing the burden of fractures on society. Thus, the purpose of this review is to examine the evidence of whether a positive effect from physical activity on bone mineral density is sustained despite decreased activity.

\section{METHOD}

A comprehensive systematic search was undertaken in the Medline, EMBASE, and Cochrane controlled trials register databases to identify studies of detraining. Medical subject headings used were "reduced physical activity" combined with "reduced exercise level", "detraining", and "unloading". These subject headings were then combined with "bone mineral density", "bone mineral content", "BMC", and "BMD". Individual search terms were also explored. Reference lists from retrieved publications and review articles identified by the search strategies above were reviewed to identify further studies. Also, from relevant papers derived from the search, a further search was undertaken by choosing the database link for "related manuscripts". The computerized searches covered the period from January 1966 to November 2009. Hard copies of retrieved publications were obtained. Only English and German lang- 
uage publications were considered. Furthermore, only papers that were published in full and in peer review journals were accepted. A final criterion was that the study populations consisted of healthy subjects.

\section{BONE AND DETRAINING}

H.M. Frost's mechanostat theory is widely accepted when it comes to the positive effects of physical activity on bone mineral density $[12,13]$. There is a general belief that if a bone is subjected to heavy loading, it will remodel itself to become stronger. However, it is not known if the same paradigm is true when it comes to decreased loading. In other words, will the bone remodel to adapt to decreased loading? The cellular and molecular mechanisms of bone loss due to detraining are poorly understood. It has been suggested that there might be different mechanism at cellular levels that mediate the load bearing adaptation of the skeleton, and the cellular mechanisms involved in unloading or decreased mechanical loading $[14,15]$. The mechanisms underlying the effects of unloading on bone have been studied in tail-suspended mice [16] that were found to have increased numbers of osteoblasts and osteocytes that were undergoing apoptosis in both trabecular and cortical bone. This was subsequently followed by increased numbers of osteoclasts, an increase in cortical porosity, and reduced trabecular and cortical widths. In other words, a reduction in mechanical stimulation eliminated the delivery of survival signals to the osteocytes, leading to cell apoptosis, the recruitment of osteoclasts, and further increases in bone resorption and bone loss [16].
The general belief is that bone tissue adapts to the stress acting on it, forming an equilibrium that covers normal daily strains. According to Frost, a threshold "the minimum effective strain" exists; when the mechanical stimulus is too low, remodelling removes bone and when it is too high creating an overload, remodelling adds bone [17]. According to his theory the remodelling occurring when the stimulus is to low results in a weak osteopenic bone susceptible to fracture. A schematic picture of the relationship between daily stress stimulus and bone remodelling is presented in Fig. (1).

In regards to the effect of physical activity on bone, it has been demonstrated that the effect is site specific $[4,5,18$, 19]. Therefore, the potential loss of bone mineral density due to detraining would most probably be a site specific phenomenon. Furthermore, studies have also suggested that the effect of physical activity on bone could vary with age and gender [20,21]. Therefore, articles relating to detraining have been analyzed and categorized according to age group, gender, and non-weight bearing versus weight bearing sites.

\section{The Effect of Detraining on Weight Bearing Bones}

\section{The Effect of Detraining in Children}

There are two studies investigating the effect of detraining in children. Fuchs et al. investigated the effect of a 7 month detraining period in children after a 7 month randomized control high impact intervention [22] (Table 1). The intervention resulted in $4 \%$ greater gains in hip and spine bone mineral content (BMC) compared to controls. Gains in both BMC and bone area at the femoral neck from

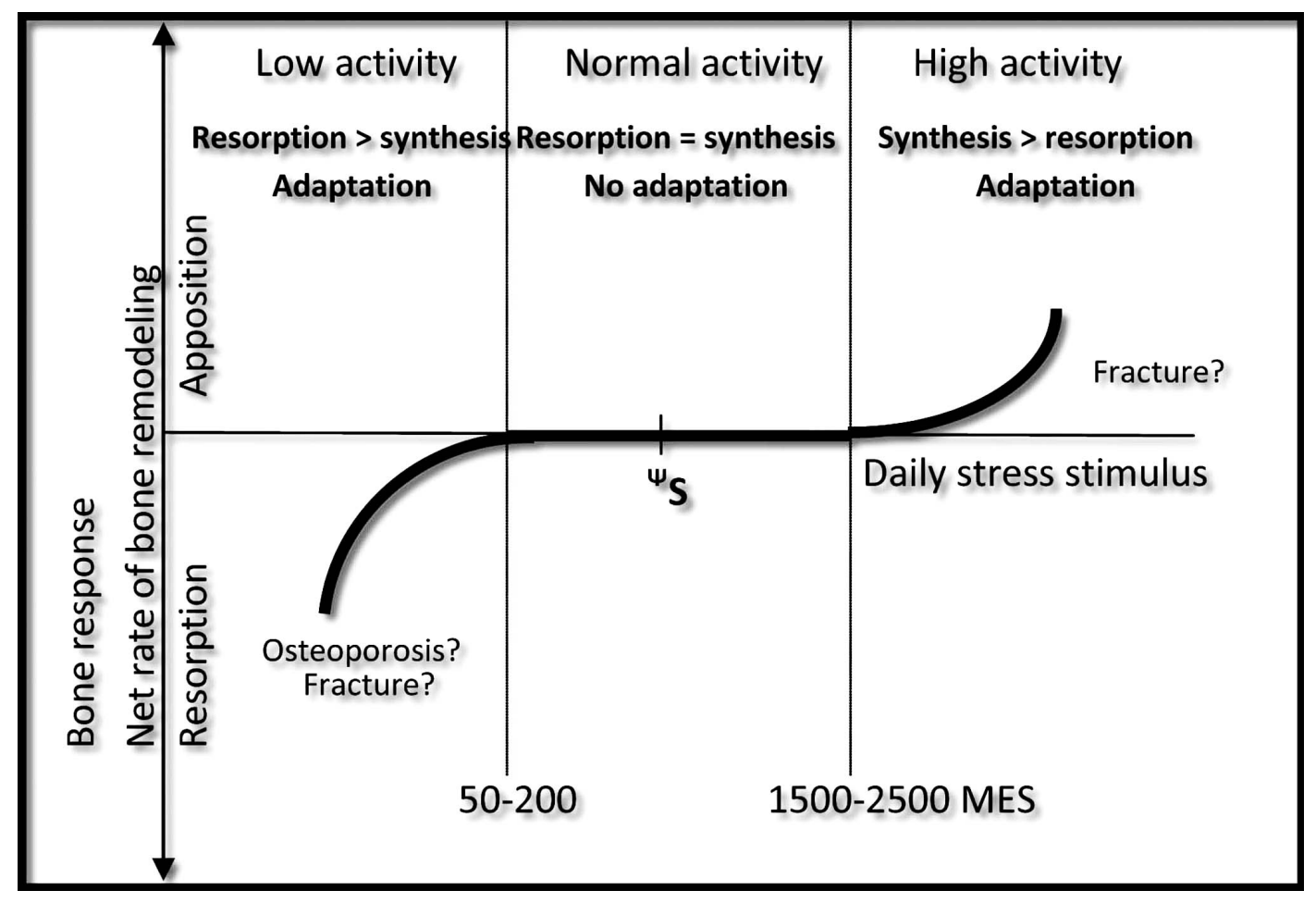

Fig. (1). A hypothetical presentation of the impact on bone remodeling from reduced or increased physical activity adopted from Turner and Carter $[54,55]$. Daily stress stimulus is presented on the $\mathrm{x}$-axis and the response of the bone to stimuli is presented on the $\mathrm{y}$-axis. The mechanobiologic response drives the bone towards equilibrium where no adaptation occurs where the resorption equals synthesis, the so called stress stimulus setpoint ${ }^{\Psi} \mathrm{S}$. There will be a net resorption when the mechanical daily stress stimulus is less than the stress stimulus setpoint and a net apposition when the mechanical daily stress is higher. 
high-impact jumping were retained after an equivalent period of detraining. Drawbacks of the study included lack of physical activity data from the intervention group and the control group and a lack of data on the amount and type of physical activity these groups performed during the detraining period. Kontulainen et al. randomized 99 girls age 12-14 years to high impact activity two times a week for nine months followed by a detraining period of 12 months [23]. After the study period the intervention group had a $4.9 \%$ greater BMC increase in the lumbar spine compared to controls. There were however no significant differences in the femoral neck or trochanter.

\section{The Effect of Detraining in Men}

In men, the evidence in the form of both cross-sectional and observational studies for a detraining effect on weight bearing bone is consistent [24-27] (Table 1). A cross-sectional study investigated the relationship between previous physical activity and BMD in 48 former weight lifters and 66 controls [24]. The athletes had trained 10 hours per week (range 4-20) for 13 years (range 1-34). They had all retired from competitive sport an average of 30 years ago (range 7 50). In ex-weight lifters 50-64 years of age, the BMD for total body and spine, but not the hip, was greater than in controls. After 65 years of age, no difference was found between the former weight lifters and their controls. Another study by Karlsson et al. investigated both young active and older retired athletes, which were divided into 3 subgroups based on age [25]. In the group of former weight lifters between 35-49 years of age, the athletes had a higher BMD for total body and the femoral neck compared to controls, the group aged 56-64 years had higher BMD for total body. However, in the oldest subgroup, there were no differences in BMD between the retired athletes and controls.

A few observational longitudinal studies have been conducted in young men where the effect of detraining on bone has been investigated [26, 27]. In a study from Northern Sweden, young male ice hockey players and controls were investigated during a 6 year period [26]. The ice hockey players were active from baseline up to 3 years; during that period, they gained significantly more femoral neck BMD and volumetric BMD (vBMD) compared to controls. Between the first and second follow up (3 to 6 years), half of the active athletes stopped their career. This group of former athletes was found to lose significantly more in femoral neck BMD and $v B M D$ compared to athletes who remained active. In a later study, the effects of detraining on bone mass during a total of 12 years was evaluated among ice hockey players, badminton players, and controls [27]. These athletes, who were 17 years of age at baseline, had higher BMDs at all measured sites (i.e., total body, femoral neck, and spine) compared to the control group. After an average of 4 years, $75 \%$ of the young men ended their active careers and were followed for approximately 8 years of detraining. Overall, no sustained benefits could be detected at any site. Furthermore, at each of the four follow up evaluations, there was an almost linear relationship observed between the amount of physical activity and BMD, especially at the femoral neck.

\section{The Effect of Detraining in Premenopausal Women}

Studies of the effect of detraining on weight bearing bones in premenopausal women have yielded inconsistent data [28-33] (Table 1). A cross-sectional retrospective study of former athletes was performed by Kahn et al. [34], who examined a cohort of 101 retired ballet dancers with a mean age of 51 years compared to 101 controls matched for menopausal status, age, height, and weight. This study concluded that there were no differences in BMD for total body, femoral neck, trochanter, hip, or for the lumbar spine between controls and ballet dancers who had been retired for a mean period of 25 years.

Three observational longitudinal studies have been performed in premenopausal athletes [28, 31, 35]. In a study of active soccer players (mean age of 18 years), former female soccer players (mean age of 43 years) were followed for 8 years and it was found that soccer players who ended their active career during the study period lost BMD at the femoral neck compared to age matched controls who gained in femoral neck BMD [28]. The former soccer players that were retired already at the start of the study had a higher BMD in the trochanter compared to controls at baseline. During follow up, these subjects lost BMD in the trochanter compared to controls who gained BMD. Thus, reduced physical activity correlated with a more rapid loss of BMD in the femoral neck in former female soccer players than controls. In a 2 year prospective study, Snow et al. observed seasonal changes in the BMDs of the hip, spine, and total body among intercollegiate gymnasts and found a consistent pattern of bone density increases over the training seasons of $1.9 \%$ to $3.7 \%$ at the hip and spine, respectively, which was followed by declines in the off seasons [31]. In lumbar spine, there was a net $4.3 \%$ increase over the study period. Thus, they found a measurable response to high magnitude loading and unloading that was consistent over 24 months of observation among all bone sites. Drawbacks of the study included the lack of a control group and only 8 subjects were observed. An observational study by Kudlac et al. did not show the same results [35]. They investigated the effect of 10 gymnasts and 9 controls. The measurements at baseline were taken 1 year prior to the cessation of an active career of these athletes. After a mean period of 4 years of retirement, the gymnasts had a greater proximal femur BMD compared to controls. Both groups had significant declines in BMDs of the femoral neck, Ward's triangle, and greater trochanter, but only gymnasts had a significant decline in lumbar spine BMD. In addition, randomized controlled studies have indicated that there is a detraining effect on BMD in premenopausal women [29, 32]. Winters et al. investigated in a randomized controlled study the effect of 6 months of detraining after a 12-month jumping and resistance program in premenopausal women aged 30-45 years [29]. They found that the percent change over the training period was significantly greater in the exercise group than in the control group for the greater trochanter and approached a significant difference for the femoral neck. After 6 months of detraining, BMDs of both sites reverted toward baseline values, whereas control values did not change. Similarly, Vuori et al. reported BMDs that returned to pretraining levels after 3 months of cessation of exercise in 12 women aged 19-27 years in the period following a 12 month period of unilateral leg presses 4 times a week in a controlled intervention study [32]. After the detraining period only the BMD values in femoral neck and calcaneus remained significant greater. 
Table 1. The Effect of Detraining on Weight Bearing Bones

\begin{tabular}{|c|c|c|c|c|c|c|c|}
\hline Authors & Study Design & Participants & $\begin{array}{l}\text { Physical } \\
\text { Activity } \\
\text { Period }\end{array}$ & $\begin{array}{l}\text { Intervention } \\
\text { /Exercise }\end{array}$ & $\begin{array}{l}\text { Detraining } \\
\text { Period }\end{array}$ & Measurements & Results \\
\hline \multicolumn{8}{|c|}{ The effect of detraining in children } \\
\hline $\begin{array}{l}\text { Kontulainen et } \\
\quad \text { al. }[23]\end{array}$ & $\mathrm{CT}$ & $\begin{array}{l}\text { IG } 5012.8 \text { years } \\
\text { C } 4912.2 \text { years }\end{array}$ & 9 months & $\begin{array}{c}50 \text { min step } \\
\text { aerobics }+ \text { extra } \\
\text { jumps } 2 \text { times a } \\
\text { week }\end{array}$ & 20 months & BMC FN, Tr, LS & $\begin{array}{l}\text { IG had significantly greater } \\
\text { gain in LS than } C\end{array}$ \\
\hline $\begin{array}{l}\text { Fuchs et al. } \\
\qquad[22]\end{array}$ & $\mathrm{CT}$ & $\begin{array}{c}37 \mathrm{IG}, 37 \mathrm{C} \text { age } \\
7 \text { years }\end{array}$ & 7 months & $\begin{array}{l}\text { High intensity } \\
\text { jumping } 3 \text { times } \\
\text { per week }\end{array}$ & 7 months & $\begin{array}{l}\text { FN BA, BMC, LS } \\
\text { BA, LS }\end{array}$ & $\begin{array}{c}\text { Gains in FN BA, BMC was } \\
\text { retained }\end{array}$ \\
\hline \multicolumn{8}{|c|}{ The effect of detraining in men } \\
\hline $\begin{array}{l}\text { Karlsson et al. } \\
{[24]}\end{array}$ & $\begin{array}{c}\text { Cross } \\
\text { sectional }\end{array}$ & $\begin{array}{c}24 \text { men } 50-64, \\
24 \text { men } 65-79 \\
\text { years }+66 \text { age } \\
\text { matched C }\end{array}$ & 13 years & Weight lifting & $\begin{array}{l}13,30 \text { years } \\
\text { respectively }\end{array}$ & $\begin{array}{l}\text { BMD TB, FN, tr, } \\
\text { W, S, H }\end{array}$ & $\begin{array}{c}\text { Young IG had greater BMD in } \\
\text { TB, S }\end{array}$ \\
\hline $\begin{array}{l}\text { Karlsson et al. } \\
{[25]}\end{array}$ & $\begin{array}{c}\text { Cross } \\
\text { sectional }\end{array}$ & $\begin{array}{lll}\text { IG1 } & 16 & 40 \pm 4 \\
\text { IG2 } & 24 & 57 \pm 5 \\
\text { IG3 } & 24 & 71 \pm 4 \\
\text { C } 133 & 48 \pm 19\end{array}$ & & Weight lifting & $25 \pm 13$ years & BMD TB, FN & $\begin{array}{c}\text { IG1 had greater BMD TB, FN } \\
\text { than C, IG2 had greater TB than } \\
\text { C }\end{array}$ \\
\hline $\begin{array}{l}\text { Gustavsson et } \\
\text { al. }[26]\end{array}$ & $\begin{array}{l}\text { Observational } \\
\text { longitudinal }\end{array}$ & $\begin{array}{c}21 \mathrm{IG} 1+22 \mathrm{IG} \\
16.7 \pm 0.6 \text { years }+ \\
25 \mathrm{C} 16.8, \text { all men }\end{array}$ & 30 months & $\begin{array}{l}\text { Ice hockey } \\
\text { playing }\end{array}$ & 40 months & $\begin{array}{l}\text { BMD TB, S, FN, } \\
\text { vBMD FN, BA } \\
\text { FN }\end{array}$ & $\begin{array}{l}\text { IG1 lost more FN BMD, vBMD } \\
\text { than IG2 and more FN vBMD } \\
\text { than C. }\end{array}$ \\
\hline $\begin{array}{l}\text { Tervo et al. } \\
\quad[27]\end{array}$ & $\begin{array}{l}\text { Observational } \\
\text { longitudinal }\end{array}$ & $\begin{array}{c}51 \text { IG1 } 17.3 \pm 1.8 \\
16 \text { IG2 } 17.2 \pm 1.3 \\
25 \text { C } 16.9 \pm 0.6 \text {, all } \\
\text { men }\end{array}$ & 2.9 years & $\begin{array}{l}\text { Badminton } \\
\text { playing, Ice } \\
\text { hockey playing }\end{array}$ & 8.2 years & BMD TB, S, FN & $\begin{array}{l}\text { IG1lost more FN BMD than } \\
\text { IG2, C }\end{array}$ \\
\hline \multicolumn{8}{|c|}{ The effect of detraining in premenopausal women } \\
\hline $\begin{array}{l}\text { Bass et al. } \\
\quad[33]\end{array}$ & $\begin{array}{c}\text { Cross } \\
\text { sectional }\end{array}$ & $\begin{array}{l}\text { IG } 3625.0 \pm 0.9 \\
\text { C } 1525.3 \pm 1.0\end{array}$ & & Gymnasts & 8 years & $\begin{array}{l}\text { BMD TB, FN, W, } \\
\quad \operatorname{tr}, \mathrm{LS}, \mathrm{A}, \mathrm{L}\end{array}$ & $\begin{array}{c}\text { IG greater BMD at TB, FN, W, } \\
\operatorname{tr}, \mathrm{A}, \mathrm{L} \text { than } \mathrm{C}\end{array}$ \\
\hline $\begin{array}{c}\text { Khan et al. } \\
{[34]}\end{array}$ & $\begin{array}{c}\text { Cross } \\
\text { sectional }\end{array}$ & $\begin{array}{l}\text { IG } 10151.1 \pm 1.4 \\
\text { C } 10151.5 \pm 1.6\end{array}$ & & Ballet training & 25.6 years & $\begin{array}{l}\text { BMD TB, H, tr, } \\
\text { Itr, LS }\end{array}$ & NS \\
\hline $\begin{array}{l}\text { Valdimarsson } \\
\text { et al. }[28]\end{array}$ & $\begin{array}{l}\text { Observational } \\
\text { longitudinal }\end{array}$ & $\begin{array}{ccc}\text { IG1 } & 35 & 18.9 \pm 4.8, \\
\text { IG2 } & 13 & 16.4 \pm 2.3 \\
\text { IG3 } & 18 & 43.2 \pm 6.2 \\
\text { C1 } 2 & 23 & 16.8 \pm 2.7 \\
\text { C2 } 2 & 24 & 45 \pm 5.3 \\
\text { years }\end{array}$ & $\begin{array}{l}\text { IG1 } \\
\text { IG3 }\end{array}$ & Soccer training & $\begin{array}{l}\text { IG1 } 5.3 \\
\text { IG3 } 17.3 \\
\text { years }\end{array}$ & $\begin{array}{l}\text { BMC TB, H, } \\
\text { BMD TB, H, S, } \\
\text { LS, W, Tr, L }\end{array}$ & $\begin{array}{l}\text { IG1 lost BMD whereas C } \\
\text { gained in FN, tr. IG1 gained } \\
\text { less BMD compared to } \mathrm{C} \text { in } \mathrm{S} \text {. } \\
\text { IG1 had still higher BMD in } \\
\text { TB, L at follow up } \\
\text { IG2 had still higher BMD in L } \\
\text { compared to C at follow up }\end{array}$ \\
\hline $\begin{array}{c}\text { Snow et al. } \\
{[31]}\end{array}$ & $\begin{array}{l}\text { Observational } \\
\text { longitudinal }\end{array}$ & $818.6 \pm 0.8$ years & $\begin{array}{l}2 \text { periods of } \\
8 \text { months } \\
\text { competitive } \\
\text { seasons }\end{array}$ & Gymnasts & $\begin{array}{l}2 \text { periods of } \\
4 \text { months off } \\
\text { seasons }\end{array}$ & $\begin{array}{c}\text { BMD TB, LS, FN, } \\
\text { Tr, TH }\end{array}$ & $\begin{array}{l}\text { Significantly seasonal trends in } \\
\text { BMD in FN, tr, TH, LS, TB }\end{array}$ \\
\hline $\begin{array}{l}\text { Kudlac et al. } \\
\qquad[35]\end{array}$ & $\begin{array}{l}\text { Observational } \\
\text { longitudinal }\end{array}$ & $\begin{array}{c}\text { IG } 1020.4 \pm 1.2 \\
\text { C } 923.8 \pm 3.6 \\
\text { years }\end{array}$ & & Gymnasts & 4 years & $\begin{array}{l}\text { BMD TB, LS, FN, } \\
\text { W, Tr }\end{array}$ & $\begin{array}{l}\text { BMD decline FN, W, Tr both } \\
\text { groups and BMD decline in LS } \\
\text { in IG }\end{array}$ \\
\hline $\begin{array}{l}\text { Vouri et al. } \\
\quad[32]\end{array}$ & $\mathrm{CT}$ & $\begin{array}{ll}\text { IG } 12 & 21.0 \pm 2.5 \\
\text { C } 12 & 22.0 \pm 3.0\end{array}$ & 12 months & $\begin{array}{l}\text { Unilateral leg } \\
\text { presses } 4 \text { times a } \\
\text { week }\end{array}$ & 3 months & $\begin{array}{l}\text { BMD, BMC LS, } \\
\text { FN, dF, P, pT, C }\end{array}$ & $\begin{array}{l}\text { BMD FN, C greater in left limb } \\
\text { after detraining compared to } \\
\text { untrained limb and C }\end{array}$ \\
\hline $\begin{array}{l}\text { Winters et al. } \\
\text { [29] }\end{array}$ & $\mathrm{CT}$ & $\begin{array}{c}\text { IG } 2939.6 \pm 4.2 \\
\text { C } 2040.5 \pm 3.3\end{array}$ & 12 months & $\begin{array}{l}\text { Jumps + resistance } \\
\text { training } 3 \text { times a } \\
\text { week }\end{array}$ & 6 months & $\begin{array}{l}\text { BMD TB, tr, FN, } \\
\text { LS }\end{array}$ & $\begin{array}{l}\text { FN BMD lower in IG compared } \\
\text { to post training }\end{array}$ \\
\hline $\begin{array}{l}\text { Kontulainen } \\
\text { et al. }[30]\end{array}$ & $\mathrm{CT}$ & $\begin{array}{l}\text { IG } 3439.6 \pm 2.2 \\
\text { C } 3138.4 \pm 2.7\end{array}$ & 18 months & $\begin{array}{c}\text { High impact } \\
\text { exercise } 3 \text { times } \\
\text { a week }\end{array}$ & 3,5 years & $\begin{array}{l}\text { BMD LS, FN, tr, } \\
\mathrm{dF}, \mathrm{P}, \mathrm{Pt}, \mathrm{C}, \mathrm{dR}\end{array}$ & $\begin{array}{l}\text { Intergroup differences favoring } \\
\text { IG at } \mathrm{FN}, \mathrm{dF}, \mathrm{P}, \mathrm{pT}, \mathrm{C}\end{array}$ \\
\hline
\end{tabular}


(Table 1) Contd....

\begin{tabular}{|c|c|c|c|c|c|c|c|}
\hline Authors & Study Design & Participants & $\begin{array}{l}\text { Physical } \\
\text { Activity } \\
\text { Period }\end{array}$ & $\begin{array}{l}\text { Intervention } \\
\text { /Exercise }\end{array}$ & $\begin{array}{l}\text { Detraining } \\
\text { Period }\end{array}$ & Measurements & Results \\
\hline \multicolumn{8}{|c|}{ The effect of detraining in postmenopausal women } \\
\hline $\begin{array}{l}\text { Kirchner et al. } \\
{[36]}\end{array}$ & $\begin{array}{l}\text { Cross } \\
\text { sectional }\end{array}$ & $\begin{array}{l}\text { IG } 18 \\
\text { C } 15\end{array}$ & & Gymnasts & 18 & $\begin{array}{l}\text { BMD TB, LS, } \\
\text { FN, W }\end{array}$ & $\begin{array}{l}\text { BMD LS, FN, } \mathrm{W} \text { greater in IG } \\
\text { than } \mathrm{C}\end{array}$ \\
\hline $\begin{array}{l}\text { Michel et al. } \\
{[38]}\end{array}$ & & $\begin{array}{l}\text { IG } 1455-77 \text { years } \\
\text { C } 14 \text { age matched }\end{array}$ & & Running & 5 years & BMD LS & $\begin{array}{l}\text { IG lost significantly BMD in LS } \\
\text { compared to C }\end{array}$ \\
\hline $\begin{array}{l}\text { Iwamoto et al. } \\
{[39]}\end{array}$ & CT & $\begin{array}{l}\text { IG1 } 764.3 \pm 3.0 \\
\text { IG2 } 865.3 \pm 4.7 \\
\text { C } 2064.9 \pm 5.7\end{array}$ & $\begin{array}{l}\text { IG } 11 \text { year } \\
\text { IG2 } 2 \text { year }\end{array}$ & $\begin{array}{l}\text { Increasing step } \\
\text { counts up to } 30 \text { of } \\
\text { baseline }+ \\
\text { resistance training } \\
+ \text { supplementation }\end{array}$ & IG1 1 year & BMD LS & $\begin{array}{c}\text { After } 1 \text { year IG1, IG2 higher } \\
\text { BMD LS than C after } 2 \text { years } \\
\text { no longer differences between } \\
\text { IG1 and C }\end{array}$ \\
\hline $\begin{array}{l}\text { Karinkanta } \\
\text { et al. }[41]\end{array}$ & CT & $\begin{array}{l}\text { IG1 } 3772.7 \pm 2.5 \\
\text { IG2 } 3772.9 \pm 2.3 \\
\text { IG3 } 3872.9 \pm 2.2 \\
\text { C } 3772.0 \pm 2.1\end{array}$ & 12 months & $\begin{array}{l}\text { IG1 resistance } \\
\text { training } \\
\text { IG2 balance } \\
\text { training } \\
\text { IG3 combination }\end{array}$ & 12 months & $\begin{array}{l}\text { DEXA HAS FN, } \\
\text { pQCT Ts }\end{array}$ & $\begin{array}{c}\text { After exercise intervention IG1 } \\
\text { greater } Z \text { than IG3. No } \\
\text { differences after detraining } \\
\text { period }\end{array}$ \\
\hline $\begin{array}{c}\text { Englund } \text { et al. } \\
\text { [42] }\end{array}$ & CT & $\begin{array}{c}\text { IG } 1872.4 \pm 3.8 \\
\text { C } 1672.4 \pm 3.6 \\
\text { years }\end{array}$ & 12 months & $\begin{array}{l}\text { Strength, } \\
\text { aerobic, balance, } \\
\text { coordination } \\
\text { exercises } 50 \mathrm{~min} \\
2 \text { times a week }\end{array}$ & 5 years & $\begin{array}{l}\text { BMD, BMC TB, } \\
\text { A, LS, FN, W }\end{array}$ & $\begin{array}{l}\text { Both groups lost BMD at } \\
\text { weight bearing sites. } \\
\text { IG had lost more BMD at FN, } \\
\text { tr, } \mathrm{W} \text { at follow up than } \mathrm{C} \text {. }\end{array}$ \\
\hline
\end{tabular}

Abbreviations: $\mathrm{IG}=$ Intervention group, $\mathrm{CG}=\mathrm{Control}$ group, $\mathrm{BMD}=$ bone mineral density, $\mathrm{BA}=$ bone area, $\mathrm{BMC}=$ bone mineral content, $\mathrm{vBMD}=\mathrm{volumetric}$ bone mineral density, $\mathrm{LS}=$ lumbar spine, $\mathrm{FN}=$ femoral neck, $\mathrm{TB}=$ total body, $\mathrm{S}=$ spine, $\mathrm{Tr}=$ trochanter, $\mathrm{W}=\mathrm{Ward}$ 's triangle, $\mathrm{H}=$ humerus, $\mathrm{dR}=$ distal radius, $\mathrm{A}=$ arms, $\mathrm{L}=$ legs, $\mathrm{ITr}=\mathrm{intertrochanter}, \mathrm{TH}=$ total hip, $\mathrm{PF}=$ proximal femur, $\mathrm{dF}=$ distal femur, $\mathrm{P}=$ patella, $\mathrm{pT}=$ proximal tibia, $\mathrm{C}=$ calcaneus, $\mathrm{DEXA}=$ dual energy $\mathrm{x}$-ray absorptiometry, $\mathrm{HAS}=$ hip strength analysis, $\mathrm{pQCT}=\mathrm{Peripheral}$ quantitative computed tomography, $\mathrm{Z}=$ section modulus, Ts=tibial shaft

However, data from these intervention studies are not in line with data presented by Kontulainen in a 5 year follow up study [30]. They investigated detraining effects after an 18 month intervention of high-impact exercise in premenopausal women, which examined 34 former trainees and 31 controls. BMDs for the lumbar spine, femoral neck, trochanter, distal femur, patella, proximal tibia, calcaneus, and dominant distal radius were measured at baseline, after 18 months, and after 5 years. BMDs of the bone sites that increased in response to the 18-month intervention (femoral neck, distal femur, patella, proximal tibia, and calcaneus) also demonstrated maintenance of this gain 3.5 years after the intervention, except for at the lumbar spine. These different results might be explained by factors such as the different types and intensity of training and that the subjects were rather active after cessation of the training period.

\section{The Effect of Detraining in Postmenopausal Women}

Studies performed in postmenopausal women have yielded different results(Table 1). Kirchner and coworkers compared BMDs between former collegiate gymnasts to age, height, and weight matched controls [36]. BMDs of the former gymnasts were significantly greater than those of controls, with a mean percentage difference between $16 \%$ and $22 \%$ for the lumbar spine, femoral neck, and Ward's area. The former gymnasts were then compared to collegeaged gymnasts. The BMDs of the former gymnasts were approximately $6 \%$ to $14 \%$ lower than those of college-aged gymnasts. However, differences between BMDs were statistically significant only at the femoral neck and Ward's area and not the lumbar spine. Duppe et al. examined BMDs of junior, senior and former soccer players and controls [37]. The 25 former players (aged 34-84 years) had ended their active careers on average 10 years previously [37]. Still, they had greater BMDs at the proximal femur and total body compared to age matched controls, despite similar current activity levels. Thus, this cross-sectional study suggests a residual benefit of prior physical activity among former athletes. However, these data are not consistent with longitudinal studies performed on the topic presented below.

Longitudinal studies of detraining after exercise intervention for weight bearing bones in postmenopausal women have shown consistent results indicating that continuous physical activity is needed to maintain the BMD gains achieved; otherwise, any benefits from exercise may be lost. Michel et al. observed the effect of running on lumbar spine BMD in runners and controls between 55-77 years of age during a 5 year period [38]. Substantial decreases in physical weight bearing activity were associated with significant bone loss in the lumbar spine. Iwamoto et al. investigated the 
effect of detraining in a cohort of postmenopausal women with osteoporosis who were randomly assigned to either a 2 year exercise training group, a 1 year exercise training plus 1 year detraining group, or a control group [39]. The intervention consisted of walking and gymnastic training. The women were all supplemented with calcium lactate $(2.0 \mathrm{~g})$ and 1-alpha-hydroxyvitamin $\mathrm{D}_{3}(1 \mu \mathrm{g}$ daily). The mean percent change in BMD compared with the baseline was significantly higher at 1 and 2 years in the exercise training group and at 1 year in the detraining group than in the control group, and did not differ significantly at 2 years between the detraining and control groups. These results indicated that continuous physical activity was needed to maintain any BMD gains achieved. Similar results were found by Dalsky et al. in a non-randomized controlled physical activity intervention consisting of walking, jogging, and stair climbing in combination with calcium supplementation [40]. Bone mineral content in lumbar spine increased 5.2\% after 9 months of training, whereas there was no significant change $(-1.4 \%)$ in the control group. After 22 months of physical activity, bone mineral content of the lumbar spine had increased $6.1 \%$ in the long-term training group. After 13 months of decreased activity, bone mass was $1.1 \%$ above baseline in the detraining group. In this investigation, not all participants completely stopped exercising during the detraining period; some just reduced their activity level. Thus, the benefits of exercise may be lost after the end of the intervention. Karinkanta et al. assessed bone properties in the tibia and femur using pQCT and DEXA one year after cessation of a 12 month randomized controlled exercise intervention in 70-78 year old women [41]. After the intervention, there was a significant between-group difference in the section modulus value for the femoral neck between the group practicing resistance training and the group practicing a combination of resistance training, balance, and jumping, which disappeared after the detraining period. Another study investigated the effect of detraining after a 12 month randomized controlled study [42]. Thirty-four women completed the intervention (18 exercisers and 16 controls) and were invited to participate in a 5 year follow up assessment. The intervention resulted in a BMD increase in Ward's triangle in the exercise group compared to controls. After the 5-year follow up, both groups sustained significant losses in BMD of the femoral neck, trochanter, and Ward's triangle during the follow up period such that there was no longer any difference between the groups for the BMD of Ward's triangle.

\section{The Effect of Detraining on Non-Weight Bearing Bones}

\section{The Effect of Detraining in Children}

To our knowledge, there have not been any studies performed investigating the effect of detraining on nonweight-bearing bones in children.

\section{The Effect of Detraining in Men}

There seems to be a difference in how trabecular and cortical bone react to detraining (Table 2). Tervo et al. investigated the effect of detraining among multiple sites and found that former athletes such as badminton players and ice hockey players that use both arms and legs in their sports lost more BMD at bone sites comprised largely of trabecular bone (hip, spine, and pelvis) than at bone sites comprised largely of cortical bone (femur, humerus, and legs) after 8 years of reduced activity [43]. Moreover, at the final follow up evaluation, former athletes still had a significantly higher BMD than controls at bone sites comprised mainly of cortical bone, such as the humerus and legs. These findings corroborate results from a Finnish observational longitudinal study that compared changes in BMC between the playing versus non-playing arm in male racket sport players after four years of decreased training [44].

\section{The Effect of Detraining in Premenopausal Women}

Regarding the effect of detraining on non-weight-bearing bones in premenopausal women, these data also seem to be consistent (Table 2). Kontulainen et al. investigated the effect of detraining on non-weight-bearing bones in premenopausal women [45]. They showed that increased arm BMD attained by racket players during their growth periods was usually maintained into adulthood, despite a subsequent reduction in activity levels. Bass et al. found similar results when comparing BMDs for active and retired female gymnasts compared to that of controls [33]. Both active female athletes and ex-athletes retired for a mean of 8 years had higher BMDs in their arms compared to controls. A third study by Heinonen et al. examined the effects of 12 months of unilateral high-resistance strength training followed by 8 months of detraining on BMC and BMDs of the proximal humerus, humeral shaft, radial shaft, ulnar shaft, and distal forearm in students [46]. Thirteen subjects trained their left upper limbs with dumbbells on average of 2.8 times per week for 12 months, which was followed by eight months detraining. Nineteen students served as controls. No differences were observed after the training or detraining periods. The lack of impact of training or detraining in this study could be due to the use of high-resistance strength training that may not have provided an effective osteogenic stimulus for bone formation.

\section{The Effect of Detraining in Postmenopausal Women}

To our knowledge there have not been any studies performed investigating the effect of detraining on nonweight-bearing bones in postmenopausal women.

\section{DISCUSSION}

The general method to avoid fractures can be divided into the following three strategies: maximizing bone mineral density gain during childhood and adolescence, minimizing the age-related decline in bone mineral density, and preventing serious falls. The first of these concepts are based on the notion that any beneficial effects are maintained despite an altered lifestyle or maintenance of an active lifestyle. It has been suggested that a high BMD from training during younger years may be preserved and that this would be protective against osteoporosis later in life [10]. However, this was only a theory and was based mostly on retrospective studies of former athletes [33, 47-50] or on shorter duration longitudinal studies [35, 44, 45, 51].

Studies that have been performed to answer the question of whether a reduction in exercise is followed by a loss of any benefits have mainly been performed in two different settings: observational studies of athletes and short-term 
Table 2. The Effect of Detraining on Non-Weight Bearing Bones

\begin{tabular}{|c|c|c|c|c|c|c|c|}
\hline Authors & Study Design & Participants & $\begin{array}{c}\text { Physical } \\
\text { Activity } \\
\text { Period }\end{array}$ & $\begin{array}{l}\text { Intervention } \\
\text { /Exercise }\end{array}$ & $\begin{array}{l}\text { Detraining } \\
\text { Period }\end{array}$ & Measurements & Results \\
\hline \multicolumn{8}{|c|}{ The effect of detraining in men } \\
\hline $\begin{array}{l}\text { Tervo et al. } \\
\quad[43]\end{array}$ & $\begin{array}{l}\text { Observational } \\
\text { longitudinal }\end{array}$ & $\begin{array}{c}\text { IG1 } 5117.2 \pm 1.3 \\
\text { IG2 } 1617.3 \pm 1.8 \\
\text { C } 2516.9 \pm 0.6\end{array}$ & 2.9 years & $\begin{array}{l}\text { Badminton playing, } \\
\text { Ice hockey playing }\end{array}$ & 8.2 years & BMD TB, S, FN & $\begin{array}{l}\text { IG1lost more FN } \\
\text { BMD than IG2, C }\end{array}$ \\
\hline $\begin{array}{l}\text { Kontulainen } \\
\text { et al. }[44]\end{array}$ & $\begin{array}{c}\text { Observational } \\
\text { longitudinal }\end{array}$ & $\begin{array}{c}\text { IG } 1326.0 \pm 5.1 \\
\text { C } 1326.2 \pm 5.9\end{array}$ & & Tennis players & 2.3 years & $\begin{array}{l}\text { BMD Hpr, Hs, Rs, } \\
\text { dR }\end{array}$ & $\begin{array}{l}\text { No changes in } \\
\text { relative side to side } \\
\text { differences in groups } \\
\text { or between groups }\end{array}$ \\
\hline \multicolumn{8}{|c|}{ The effect of detraining in premenopausal women } \\
\hline Bass et al. [46] & $\begin{array}{c}\text { Cross } \\
\text { sectional }\end{array}$ & $\begin{array}{c}\text { IG } 3625.0 \pm 0.9 \\
\text { C } 1525.3 \pm 1.0\end{array}$ & & Gymnasts & 8 years & $\begin{array}{l}\text { BMD TB, FN, } \\
\text { W, tr, LS, A, L }\end{array}$ & $\begin{array}{c}\text { IG greater BMD at } \\
\text { TB, FN, W, tr, A, L } \\
\text { than C }\end{array}$ \\
\hline $\begin{array}{l}\text { Kontulainen } \\
\text { et al. }[45]\end{array}$ & $\begin{array}{c}\text { Observational } \\
\text { longitudinal }\end{array}$ & $\begin{array}{c}\text { IG1 } 3621.6 \pm 7.6 \\
\text { IG2 } 2839.4 \pm 10.5 \\
\text { C } 2728.6 \pm 10.0\end{array}$ & & Racket sports & $\begin{array}{c}5 \text { years } \\
\text { IG1, IG2 educed } \\
\text { activity from } 4.7, \\
4.0 \text { times a week } \\
\text { to } 1.4,2.0 \text { times a } \\
\text { week resp. }\end{array}$ & $\begin{array}{l}\text { BMC Hpr, Hs, } \\
\text { dR }\end{array}$ & $\begin{array}{l}\text { IG1 decreased in } \\
\text { relative side to side } \\
\text { difference in } \mathrm{Hpr}, \mathrm{Rd} \\
\text { IG2 increased in } \\
\text { relative side to side } \\
\text { difference in } \mathrm{Hpr}, \mathrm{Rd}\end{array}$ \\
\hline $\begin{array}{l}\text { Heinonen } \\
\text { et al. }[47]\end{array}$ & $\mathrm{CT}$ & $\begin{array}{l}\text { IG } 1323.8 \pm 5.0 \\
\text { C } 1925.7 \pm 5.2\end{array}$ & 1 year & $\begin{array}{l}\text { Unilateral upper } \\
\text { strength training } 5 \\
\text { times a week }\end{array}$ & 8 months & $\begin{array}{l}\text { BMC, BMD Hpr, } \\
\text { Hs, Rs, Us, dF } \\
\text { BMD C }\end{array}$ & NS \\
\hline
\end{tabular}

Abbreviations: $\mathrm{IG}=$ Intervention group, $\mathrm{CG}=\mathrm{Control}$ group, $\mathrm{BMD}=$ bone mineral density, $\mathrm{TB}=$ total body, $\mathrm{S}=$ spine, $\mathrm{FN}=$ femoral neck, $\mathrm{Hpr}=\mathrm{Humerus}$ proximal, $\mathrm{Rs}=\mathrm{radial}$ shaft, $\mathrm{dR}=$ distal radius, $\mathrm{W}=$ Ward's triangle, $\mathrm{tr}=$ trochanter, $\mathrm{LS}=$ lumbar spine, $\mathrm{A}=\mathrm{arms}, \mathrm{L}=\mathrm{legs}, \mathrm{C}=$ calcaneus, $\mathrm{Us}=\mathrm{Ulnar}$ shaft, $\mathrm{dF}=\mathrm{distal}$ forearm, $\mathrm{Hs}=\mathrm{Humeral}$ shaft, $\mathrm{NS}=$ non significant.

randomized controlled studies. Most prospective data following athletes indicate a higher BMD loss in weightbearing bones among retired athletes compared to athletes who continue with exercise or controls. This seems also to be validated by randomized controlled studies that have been performed. These findings seem to be consistent among all age groups and for both genders except in children, although there are a few retrospective cross-sectional studies that are not in accordance with these findings. These discrepancies among studies with lower levels of evidence (such as crosssectional studies) could be due to secular trends in exercise regimes, more sedentary living, or continued higher physical activity levels in the former athletes. In conclusion, it seems that weight bearing bone (especially the femoral neck) is highly sensitive to changes in levels of physical activity. This may be related to the fact that weight-bearing physical activity likely results in high strain at the femoral neck and that the femoral neck is composed of a rather high amount of trabecular bone. These studies indicate that a high peak bone mass from previous training is not protective against the development of osteoporosis later in life at trabecular bone sites if athletic activity is not maintained.

When investigating the effect of physical activity on nonweight-bearing bone, there are only a few studies that have investigated the effect of detraining. These data were gathered from premenopausal women and young men and show a consistent residual effect of physical activity on BMD. It might be that bone mass in long bones such as the humerus and legs (consisting of more cortical bones) are lost a slower rate than at sites consisting of more trabecular bone, such as the femoral neck [52]. However, with respect to protection for fractures later in life, it is important to note that fragility fractures are predominantly sustained at sites rich in trabecular bone, such as the proximal femur.

From the studies published to date, there seems to be a difference in how bone sites consisting of predominantly trabecular bone or cortical bone respond to detraining. Exercise-induced bone gain is lost predominantly in bone sites rich in trabecular bone. A possible explanation for these divergent results is unknown and needs investigating. Nevertheless, it can be speculated that the differential effect of reduced amounts of physical activity on cortical and trabecular bone is due to different turnover times [53]. In general, randomized and controlled studies with an adequate sample size, as well as retention of subjects with compliance, need to be carried out along with ample follow-up times in order to shed light on the effect of detraining on bone mineral density.

\section{CONCLUSIONS}

In conclusion, it seems that weight-bearing bone (especially the femoral neck) is highly sensitive to changes in levels of physical activity. These studies indicate that a high peak bone mass from previous training is not protective against the development of osteoporosis later in life at bone sites rich in trabecular bone if the athletic activity is not maintained.

Few studies have investigated the effect of detraining on non-weight-bearing bones; therefore, any available data should be interpreted cautiously. However, it seems that 
there is a consistent residual effect of physical activity on $\mathrm{BMD}$, at least among the young men and premenopausal women who participated in these studies.

Randomized and controlled studies with an adequate sample size, as well as retention of subjects with compliance, need to be carried out with ample follow-up time in order to shed light on the effect of detraining on bone mineral density. This knowledge is essential if physical activity is to be regarded as evidence-based therapy and cost-effective treatment when it comes to increasing bone mineral density, which may ultimately reduce the burden of fractures on society.

\section{REFERENCES}

[1] Browner WS, Pressman AR, Nevitt MC, Cummings SR. Mortality following fractures in older women. The study of osteoporotic fractures. Arch Intern Med 1996; 156(14): 1521-5.

[2] Cooper C, Atkinson EJ, Jacobsen SJ, O'Fallon WM, Melton LJd. Population-based study of survival after osteoporotic fractures. Am J Epidemiol 1993; 137(9): 1001-5.

[3] Nevitt MC, Ettinger B, Black DM, et al. The association of radiographically detected vertebral fractures with back pain and function: a prospective study. Ann Intern Med 1998; 128(10): 793800.

[4] Nordstrom A, Hogstrom M, Nordstrom P. Effects of different types of weight-bearing loading on bone mass and size in young males: a longitudinal study. Bone 2008; 42(3): 565-71.

[5] Gustavsson A, Thorsen K, Nordstrom P. A 3-year longitudinal study of the effect of physical activity on the accrual of bone mineral density in healthy adolescent males. Calcif Tissue Int 2003; 73(2): 108-14.

[6] Heinonen A, Sievanen H, Kannus P, Oja P, Pasanen M, Vuori I. High-impact exercise and bones of growing girls: a 9-month controlled trial. Osteoporos Int 2000; 11(12): 1010-7.

[7] Heinonen A, Kannus P, Sievanen H, et al. Randomised controlled trial of effect of high-impact exercise on selected risk factors for osteoporotic fractures. Lancet 1996; 348(9038): 1343-7.

[8] MacKelvie KJ, Khan KM, Petit MA, Janssen PA, McKay HA. A school-based exercise intervention elicits substantial bone health benefits: a 2-year randomized controlled trial in girls. Pediatrics 2003; 112 (6 Pt 1): e447.

[9] Nelson ME, Fiatarone MA, Morganti CM, Trice I, Greenberg RA, Evans WJ. Effects of high-intensity strength training on multiple risk factors for osteoporotic fractures: a randomized controlled trial. JAMA 1994; 272(24): 1909-14.

[10] Kannus P. Preventing osteoporosis, falls, and fractures among elderly people. Promotion of lifelong physical activity is essential. BMJ 1999; 318(7178): 205-6.

[11] Nordstrom A, Karlsson C, Nyquist F, Olsson T, Nordstrom P, Karlsson M. Bone loss and fracture risk after reduced physical activity. J Bone Miner Res 2005; 20(2): 202-7.

[12] Frost HM. Bone "mass" and the "mechanostat": a proposal. The Anatomical Rec 1987; 219(1): 1-9.

[13] Frost HM. Bone's mechanostat: a 2003 update. Anat Rec 2003; 275A(2): 1081-101.

[14] Lin C, Jiang X, Dai Z, et al. Sclerostin mediates bone response to mechanical unloading through antagonizing Wnt/beta-catenin signaling. J Bone Miner Res 2009; 24(10): 1651-61.

[15] Lee K, Jessop H, Suswillo R, Zaman G, Lanyon L. Endocrinology: bone adaptation requires oestrogen receptor-alpha. Nature 2003; 424(6947): 389.

[16] Aguirre JI, Plotkin LI, Stewart SA, et al. Osteocyte apoptosis is induced by weightlessness in mice and precedes osteoclast recruitment and bone loss. J Bone Miner Res 2006; 21(4): 605-15.

[17] Frost HM. Vital biomechanics: proposed general concepts for skeletal adaptations to mechanical usage. Calcif Tissue Int 1988; 42(3): 145-56.

[18] Morel J, Combe B, Francisco J, Bernard J. Bone mineral density of 704 amateur sportsmen involved in different physical activities. Osteoporos Int 2001; 12(2): 152-7.
[19] Nordstrom P, Lorentzon R. Site-specific bone mass differences of the lower extremities in 17-year- Old ice hockey players. Calcif Tissue Int 1996; 59(6): 443-8.

[20] MacKelvie KJ, Khan KM, McKay HA. Is there a critical period for bone response to weight-bearing exercise in children and adolescents? a systematic review. Br J Sports Med 2002; 36(4): 250-7; discussion 7.

[21] Hogstrom M, Nordstrom A, Alfredson H, Lorentzon R, Thorsen K, Nordstrom P. Current physical activity is related to bone mineral density in males but not in females. Int J Sports Med 2007; 28(5): 431-6.

[22] Fuchs RK, Snow CM. Gains in hip bone mass from high-impact training are maintained: a randomized controlled trial in children. J Pediatr 2002; 141(3): 357-62.

[23] Kontulainen SA, Kannus PA, Pasanen ME, et al. Does previous participation in high-impact training result in residual bone gain in growing girls? One year follow-up of a 9-month jumping intervention. Int J Sports Med 2002; 23(8): 575-81.

[24] Karlsson MK, Johnell O, Obrant KJ. Is bone mineral density advantage maintained long-term in previous weight lifters? Calcif Tissue Int 1995; 57(5): 325-8.

[25] Karlsson MK, Hasserius R, Obrant KJ. Bone mineral density in athletes during and after career: a comparison between loaded and unloaded skeletal regions. Calcif Tissue Int 1996; 59(4): 245-8.

[26] Gustavsson A, Olsson T, Nordstrom P. Rapid loss of bone mineral density of the femoral neck after cessation of ice hockey training: a 6-year longitudinal study in males. J Bone Miner Res 2003; 18(11): 1964-9.

[27] Tervo T, Nordstrom P, Neovius M, Nordstrom A. Constant adaptation of bone to current physical activity level in men: a 12year longitudinal study. J Clin Endocrinol Metab 2008; 93(12): 4873-9.

[28] Valdimarsson O, Alborg HG, Duppe H, Nyquist F, Karlsson M. Reduced training is associated with increased loss of BMD. J Bone Miner Res 2005; 20(6): 906-12.

[29] Winters KM, Snow CM. Detraining reverses positive effects of exercise on the musculoskeletal system in premenopausal women. J Bone Miner Res 2000; 15(12): 2495-503.

[30] Kontulainen S, Heinonen A, Kannus P, Pasanen M, Sievanen H, Vuori I. Former exercisers of an 18-month intervention display residual aBMD benefits compared with control women 3.5 years post-intervention: a follow-up of a randomized controlled highimpact trial. Osteoporos Int 2004; 15(3): 248-51.

[31] Snow CM, Williams DP, LaRiviere J, Fuchs RK, Robinson TL. Bone gains and losses follow seasonal training and detraining in gymnasts. Calcif Tissue Int 2001; 69(1): 7-12.

[32] Vuori I, Heinonen A, Sievanen H, Kannus P, Pasanen M, Oja P. Effects of unilateral strength training and detraining on bone mineral density and content in young women: a study of mechanical loading and deloading on human bones. Calcif Tissue Int 1994; 55(1): 59-67.

[33] Bass S, Pearce G, Bradney M, et al. Exercise before puberty may confer residual benefits in bone density in adulthood: studies in active prepubertal and retired female gymnasts. J Bone Miner Res 1998; 13(3): 500-7.

[34] Khan KM, Green RM, Saul A, et al. Retired elite female ballet dancers and nonathletic controls have similar bone mineral density at weightbearing sites. J Bone Miner Res 1996; 11(10): 1566-74.

[35] Kudlac J, Nichols DL, Sanborn CF, DiMarco NM. Impact of detraining on bone loss in former collegiate female gymnasts. Calcif Tissue Int 2004; 75(6): 482-7.

[36] Kirchner EM, Lewis RD, O'Connor PJ. Effect of past gymnastics participation on adult bone mass. J Appl Physiol 1996; 80(1): 22632.

[37] Duppe H, Gardsell P, Johnell O, Ornstein E. Bone mineral density in female junior, senior and former football players. Osteoporos Int 1996; 6(6): 437-41.

[38] Michel BA, Lane NE, Bjorkengren A, Bloch DA, Fries JF. Impact of running on lumbar bone density: a 5-year longitudinal study. J Rheumatol 1992; 19(11): 1759-63.

[39] Iwamoto J, Takeda T, Ichimura S. Effect of exercise training and detraining on bone mineral density in postmenopausal women with osteoporosis. J Orthop Sci 2001; 6(2): 128-32.

[40] Dalsky GP, Stocke KS, Ehsani AA, Slatopolsky E, Lee WC, Birge SJ, Jr. Weight-bearing exercise training and lumbar bone mineral 
content in postmenopausal women. Ann Intern Med 1988; 108(6): 824-8.

[41] Karinkanta S, Heinonen A, Sievanen H, Uusi-Rasi K, Fogelholm M, Kannus P. Maintenance of exercise-induced benefits in physical functioning and bone among elderly women. Osteoporos Int 2009; 20(4): 665-74.

[42] Englund U, Littbrand H, Sondell A, Bucht G, Pettersson U. The beneficial effects of exercise on BMD are lost after cessation: a 5year follow-up in older post-menopausal women. Scand J Med Sci Sports 2009; 19(3): 381-8.

[43] Tervo T, Nordstrom P, Neovius M, Nordstrom A. Reduced physical activity corresponds with greater bone loss at the trabecular than the cortical bone sites in men. Bone 2009; 45(6): 1073-8.

[44] Kontulainen S, Kannus P, Haapasalo H, et al. Changes in bone mineral content with decreased training in competitive young adult tennis players and controls: a prospective 4-yr follow-up. Med Sci Sports Exerc 1999; 31(5): 646-52.

[45] Kontulainen S, Kannus P, Haapasalo H, et al. Good maintenance of exercise-induced bone gain with decreased training of female tennis and squash players: a prospective 5-year follow-up study of young and old starters and controls. J Bone Miner Res 2001; 16(2): 195-201.

[46] Heinonen A, Sievanen H, Kannus P, Oja P, Vuori I. Effects of unilateral strength training and detraining on bone mineral mass and estimated mechanical characteristics of the upper limb bones in young women. J Bone Miner Res 1996; 11(4): 490-501.
[47] Lynch NA, Ryan AS, Evans J, Katzel LI, Goldberg AP. Older elite football players have reduced cardiac and osteoporosis risk factors. Med Sci Sports Exerc 2007; 39(7): 1124-30.

[48] Zanker CL, Osborne C, Cooke CB, Oldroyd B, Truscott JG. Bone density, body composition and menstrual history of sedentary female former gymnasts, aged 20-32 years. Osteoporos Int 2004; 15(2): 145-54.

[49] Khan KM, Bennell KL, Hopper JL, et al. Self-reported ballet classes undertaken at age 10-12 years and hip bone mineral density in later life. Osteoporos Int 1998; 8(2): 165-73.

[50] Nilsson M, Ohlsson C, Eriksson AL, et al. Competitive physical activity early in life is associated with bone mineral density in elderly Swedish men. Osteoporos Int 2008; 19(11): 1557-66.

[51] Nordstrom A, Olsson T, Nordstrom P. Sustained benefits from previous physical activity on bone mineral density in males. J Clin Endocrinol Metab 2006; 91(7): 2600-4.

[52] Kuiper JW, Van Kuijk C, Grashuis JL. Distribution of trabecular and cortical bone related to geometry: a quantitative computed tomography study of the femoral neck. Invest Radiol 1997; 32(2): 83-9.

[53] Kanis J. Textbook of osteoporosis. In: LB, Ed. Cambridge, Great Britain 1996: pp. 11-12.

[54] Turner $\mathrm{CH}$. Homeostatic control of bone structure: an application of feedback theory. Bone 1991; 12(3): 203-17.

[55] Carter DR. The relationship between in vivo strains and cortical bone remodeling. Crit Rev Biomed Eng 1982; 8(1): 1-28.

(C) Nordström and Nordström; Licensee Bentham Open.

This is an open access article licensed under the terms of the Creative Commons Attribution Non-Commercial License (http://creativecommons.org/licenses/by$\mathrm{nc} / 3.0 /$ ), which permits unrestricted, non-commercial use, distribution and reproduction in any medium, provided the work is properly cited. 